\title{
Corrigendum: Fragile Gene WWOX Guides TFAP2A/TFAP2C-Dependent Actions Against Tumor Progression in Grade II Bladder Cancer
}

\author{
Damian Kołat ${ }^{*}$, Żaneta Kałuzińska, Andrzej K. Bednarek and Elżbieta Płuciennik \\ Department of Molecular Carcinogenesis, Medical University of Lodz, Łódź, Poland
}

Keywords: bladder cancer, WWOX, TFAP2A, TFAP2C, AP-2alpha, AP-2gamma

\section{A Corrigendum on}

\section{OPEN ACCESS}

Approved by:

Frontiers Editorial Office, Frontiers

Media SA, Switzerland

*Correspondence:

Damian Kołat

damian.kolat@stud.umed.lodz.pl

Specialty section:

This article was submitted to Molecular and Cellular Oncology,

a section of the journal

Frontiers in Oncology

Received: 02 July 2021

Accepted: 05 July 2021

Published: 26 August 2021

Citation:

Kołat D, Kałuzińska Z,

Bednarek AK and Ptuciennik E (2021) Corrigendum: Fragile Gene WWOX Guides TFAP2A

TFAP2C-Dependent Actions

Against Tumor Progression

in Grade II Bladder Cancer.

Front. Oncol. 11:735435.

doi: 10.3389/fonc.2021.735435
Fragile Gene WWOX Guides TFAP2A/TFAP2C-Dependent Actions Against Tumor Progression in Grade II Bladder Cancer

By Kołat D, Kałuzinska $\dot{Z}$ and Płuciennik E (2021). Front. Oncol. 11:621060. doi: 10.3389/ fonc.2021.621060

Andrzej K. Bednarek was not included as an author in the published article. The corrected Author Contributions Statement appears below.

The authors apologize for this error and state that this does not change the scientific conclusions of the article in any way. The original article has been updated.

\section{AUTHOR CONTRIBUTIONS}

DK and $\mathrm{AKB}$ conceptualized the article. DK, $\mathrm{ZK}, \mathrm{AKB}$, and EP established methodology. DK and $\dot{Z} K$ were responsible for software. $\mathrm{AKB}$ and $\mathrm{EP}$ supervised the article. DK and $\dot{\mathrm{Z} K}$ visualized the results. DK wrote the original draft. DK, $\dot{Z} K$, and EP reviewed and edited the article.

Publisher's Note: All claims expressed in this article are solely those of the authors and do not necessarily represent those of their affiliated organizations, or those of the publisher, the editors and the reviewers. Any product that may be evaluated in this article, or claim that may be made by its manufacturer, is not guaranteed or endorsed by the publisher.

Copyright (c) 2021 Kołat, Kałuzinska, Bednarek and Ptuciennik. This is an open-access article distributed under the terms of the Creative Commons Attribution License (CC BY). The use, distribution or reproduction in other forums is permitted, provided the original author(s) and the copyright owner(s) are credited and that the original publication in this journal is cited, in accordance with accepted academic practice. No use, distribution or reproduction is permitted which does not comply with these terms. 